\title{
Ethanol extract of Cissampelos sympodialis ameliorates lung tissue damage in streptozotocin-induced diabetic rats
}

\author{
Tessio David de Medeiros ${ }^{1}$, Annyelly Tavares Pereira ${ }^{2}$, Flavio Santos da Silva ${ }^{3}$, \\ Raul Hernandes Bortolin ${ }^{2}$, Karinna Veríssimo Meira Taveira ${ }^{1}$, Bento João da Graça \\ Azevedo Abreu', Adriana Augusto de Rezende², Naisandra Bezerra da Silva Farias', \\ José Maria Barbosa Filho ${ }^{4}$, Karina Carla de Paula Medeiros ${ }^{1^{*}}$
}

\begin{abstract}
${ }^{1}$ Departament of Morphology, Biosciences Center, Federal University of Rio Grande do Norte, Natal, RN, Brazil, ${ }^{2}$ Department of Clinical and Toxicological Analysis, Federal University of Rio Grande do Norte, Natal, RN, Brazil, ${ }^{3}$ Departament of Health Sciences, Federal Rural University of Semiarid Region, Mossoró, Brazil, ${ }^{4}$ Laboratoty of Pharmaceutics Tecnology - Federal University of Paraiba, João Pessoa, PB, Brazil
\end{abstract}

\begin{abstract}
Diabetes Mellitus (DM) is a metabolic syndrome characterized by hyperglycemia. Chronic complications affect a number of organs, including the lungs. Cissampelos sympodialis Eichl (Menispermaceae) is a plant used to treat respiratory diseases. The aim of this study was to evaluate the effect of Cissampelos sympodialis extract (CSE) in lungs of diabetic rats. We used 30 Wistar rats divided into three groups: control group (CG), diabetic group (DG) and diabetic Cissampelos sympodialis treatment group (DTG). Diabetes was induced by streptozotocin ( $40 \mathrm{mg} / \mathrm{kg}$ i.v.). The CSE ( $400 \mathrm{mg} / \mathrm{kg}$, po) was administered daily, during four weeks, beginning one week after the onset of DM. The treatment with CSE was not able to reduce blood glucose levels after streptozotocin injection. However, it was able to decrease cholesterol and triglycerides and prevent damage on pancreatic islets morphology. Additionally, morphological alterations such as alveolar septa loss, inflammatory infiltrate and fibrosis were seen in lung tissue of rats with DM, and treatment with CSE apparently reversed these histopathological findings. Thus, CSE treatment reduced the lipid profile and restored the lung architecture of diabetic animals by a mechanism independent of glycemia and which might be associated with the reduction of the damage on the pancreatic islets.
\end{abstract}

Keywords: Cissampelos sympodialis. Diabetes. Lung. Pancreatic islets. Lipid profile.

\section{INTRODUCTION}

Diabetes Mellitus (DM) is a diffuse endocrine disease, characterized by metabolic abnormalities and long-term complications due to hyperglycemia. Approximately $30 \%$ of all newborn children have the genetic risk for type $1 \mathrm{DM}$ and a smaller percentage of those children progress to the clinical disease (MejíaLeón et al., 2015). Additional factors are also involved in type $1 \mathrm{DM}$ pathogenesis, such as viral infections, intestinal inflammation, and nutritional factors, which are required to trigger the disease in genetically predisposed individuals (Kinip, Simell, 2012). Among the main

*Correspondence: karinapm@yahoo.com and most common chronic complications of DM are micro and macrovascular disorders related to the renal, cardiovascular and nervous systems (Chawla, Chawla, Jaggi, 2016). However, in the last two decades, clinical and experimental studies have revealed morphofunctional alterations in the respiratory system (Popov, Simionescu, 1997; Davis et al., 2000; Naso et al., 2010b). The impact of DM on the respiratory system is characterized by abnormalities in pulmonary function, as well as decreased elasticity, lung volume and gas transfer (Goldman, 2003; Walter et al., 2003). Structural changes in the basal membrane of the pulmonary capillary endothelium also occur in DM, with thickened alveolar-capillary membrane inflammatory infiltrate, edema, hemorrhage and congestion (Weynand et al., 1999; Özşahin et al., 2006; Hagiwara et al., 2011). Although these alterations were confirmed clinically and in experimental models, 
few studies have investigated the physiopathological mechanisms involving pulmonary complications in the type 1 DM model (Naso et al., 2010a).

A number of therapies with plant extract have been used to reverse the complications caused by DM (Halim et al., 2002; Naso et al., 2010a; Shukri et al., 2011). Cissampelos sympodialis Eichl. (Menispermaceae) is a plant popularly known in Northeast Brazil as 'Milona' (Porto, Lima, Agra, 2008). This species is commonly found in semiarid regions of the country and its leaves and roots are used in traditional medicine to treat arthritis, rheumatism and respiratory diseases (Agra, França, Barbosa-Filho, 2007). Phytochemical analysis of the extract showed a significant presence of alkaloids (Barbosa Filho, Agra, Thomas, 1997; Marinho et al., 2012). Quality control studies have shown that both alcoholic fractions of the leaves and alcoholic fractions of the roots present alkaloids as their principal compounds, and warifteine is their common chemical marker. (Barbosa Filho, Agra, Thomas, 1997; Marinho, Barbosa-Filho, Oliveira, 2012; Aragão, 2012) Crude ethanolic extract was standardized using warifteine and methylwarifteine as markers that were also found in the total alkaloid fraction (TAF-Cs) $[16,17]$. Studies were carried out with these components and showed different pharmacological effect on the hepatic (Melo et al., 2003), nervous (Almeida et al., 2005), cardiovascular (Cavalcante et al., 2011), immune (Vieira et al., 2012) and gastrointestinal systems (De Sales et al., 2015). Several studies demonstrated that the respiratory system exhibited improved function in an experimental model of allergic asthma (Batista-Lima et al., 2001; Costa et al., 2008; Cerqueira-Lima et al., 2010; Bezerra-Santos et al., 2012, Vieira et al., 2013).

Considering the therapeutic effect of Cissampelos Sympodialis extract (CSE) and its secondary metabolites on the physiopathology of the respiratory system, the present study aimed assessing, for the first time, the effect of CSE on a model of rats with streptozotocin-induced DM, evaluating clinical and biochemical parameters, in addition to morphological analysis of lung and pancreatic tissue.

\section{MATERIAL AND METHODS}

\section{Animals}

All animal procedures were approved by the Animal Research Ethics Committee of Federal University of Rio Grande do Norte (CEUA-UFRN), under the number 010/2012 and were done in accordance with the International Guiding Principles for Biomedical Research
Involving Animals (CIOMS, ICLAS, 2012). Thirty male Wistar rats (200-300 g) were obtained from the breeding colony of the Center for Health Sciences - UFRN. The animals were housed in standard polypropylene cages and maintained under controlled room temperature $\left(22 \pm 2{ }^{\circ} \mathrm{C}\right)$ and humidity $(55 \pm 5 \%)$ with $12: 12 \mathrm{~h}$ light and dark cycle.

\section{Alcoholic extract of leaves of Cissampelos sympodialis Eichl.}

Cissampelos sympodialis Eichl, was obtained at the Botanical Garden of UFPB/Brazil (voucher species Agra 1456). Approximately $3 \mathrm{~kg}$ of fresh leaves were collected, dried at $50^{\circ} \mathrm{C}$ and pulverized. The leaves were powdered and subjected to three successive alcohol extractions in a percolator at room temperature $\left(25-30{ }^{\circ} \mathrm{C}\right)$. The CSE was obtained with a mixture of water and ethanol $(30 / 70 \mathrm{v} / \mathrm{v})$. Then solvent was removed by using rotavapor at a temperature of $60{ }^{\circ} \mathrm{C}$ under reduced pressure, and the dry weight of the extract was $79.9 \%$ based on the present solid waste. The extract showed $34 \%$ of solubility in water.

\section{Experimental protocol and groups}

DM was induced by a single injection of streptozotocin i.v. (STZ, Sigma Chemical Company, St. Louis, MO, EUA) at a dose of $40 \mathrm{mg} / \mathrm{kg}$ of body weight. STZ was dissolved in sodium citrate buffer (0.1 M, pH 4.5) (Carvalho, Carvalho, Ferreira, 2003). The levels of plasma glucose were determined and those rats with fasting glucose $>250 \mathrm{mg} / \mathrm{dL}$ served as diabetic rats. Treatment with CSE (400 mg/kg) was started one week after STZ injection (Figure 1). The animals were separated into three groups ( $\mathrm{n}=10$ per group). CSE was dissolved in vehicle solution and administered orally using an intragastric tube during a period of 30 days.

- CG, control group (vehicle treated.)

- DG, diabetic group

- DTG, diabetic + CSE treatment (400 mg/kg) group

At the end of the experimental period, the animals were euthanized by exsanguination after anesthesia with ketamine and xylazine. Then, blood was collected and right lungs were dissected out.

\section{Biochemical and clinical analyses}

During the experimental period, body weight and water intake of each group were evaluated. These parameters were analyzed following the (Lerco et al., 2003). The blood samples were placed into a testing tube with heparin (Liquemine) to avoid coagulation. 
The material was then centrifuged at $1.800 \times \mathrm{g}$ for 15 minutes. The precipitate was discarded and the plasma removed. To determine glucose, cholesterol and triglycerides levels we used the colorimetric enzymatic test (Kit Labtest, Bio Diagnostica) and absorbance was measured in spectrophotometer (CARY 3E-UV-Visible Spectrophotometer Varian).

\section{Histopathologic analyses of pancreas and lung}

For the histological analysis, the samples were fixed and embedded in paraffin. Using a microtome, the paraffin blocks were cut into $3-\mu \mathrm{m}$ seriate sections. In the dehydration phase, the structures went through three containers with absolute alcohol and two containers with xylol. In the staining phase, the lungs and pancreatic tissue were immersed in hematoxylin-eosin. Lung section was also immersed in picrosirius red. Reading was performed with light microscopy (Nikon Labophot) at $100 \times$. Histopathological alterations were assessed by two different pathologists in a blind fashion. The pancreatic islet area was measured with the ImageJ software (NIH, Bethesda, MD, USA). We selected 10 randomly areas at high-power field (100x) of each blind sample. The characteristics of lung damage include changes of alveolar wall, edematous, polymorphonuclear leukocytes (PMN) infilltration and expansion of the connective tissue in the alveolocapillary space. Inflammation and expansion of the connective tissue in the alveolocapillary space was scored $(0$, normal, 1 , mild, 2 , moderate, 3 , severe $)$ by a pathologist and overall lung injury was further calculated according to the sum of the score.

\section{Statistical analysis}

Data were expressed as mean $\pm \mathrm{SD}$. Comparisons were performed by one way ANOVA with Bonferroni post hoc test using the software GraphPad Prism version 5.0 (GraphPad Software Inc., San Diego CA, EUA). Results with $\mathrm{P}<0.05$ were considered statistically significant.

\section{RESULTS}

\section{Clinical analyses}

Clinical assessment revealed that diabetic animals (DG) lost weight $(\mathrm{P}<0.001)$ and had increased water ingestion $(\mathrm{P}<0.001)$ compared to $\mathrm{CG}$ (Figure $2 \mathrm{~B}$ and $2 \mathrm{C})$. Treatment with CSE showed no improvement in these clinical aspects (weight loss and polydipsia) when compared with DG (Figure 2B and 2C).

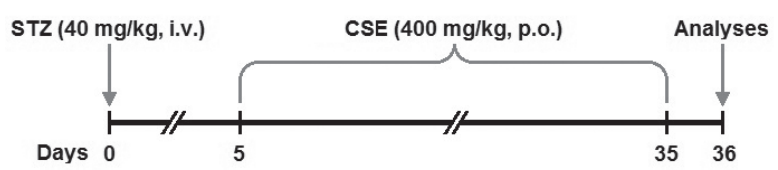

FIGURE 1 - Experimental design.
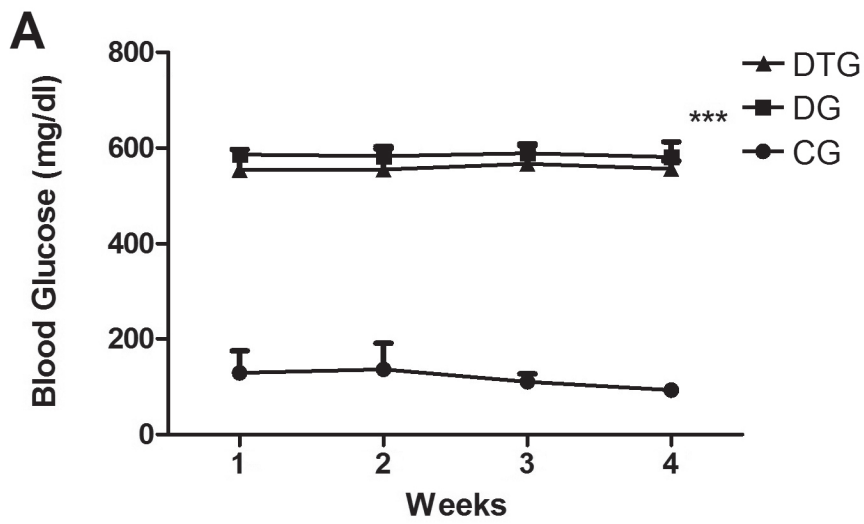

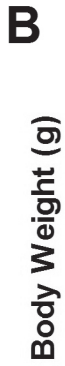
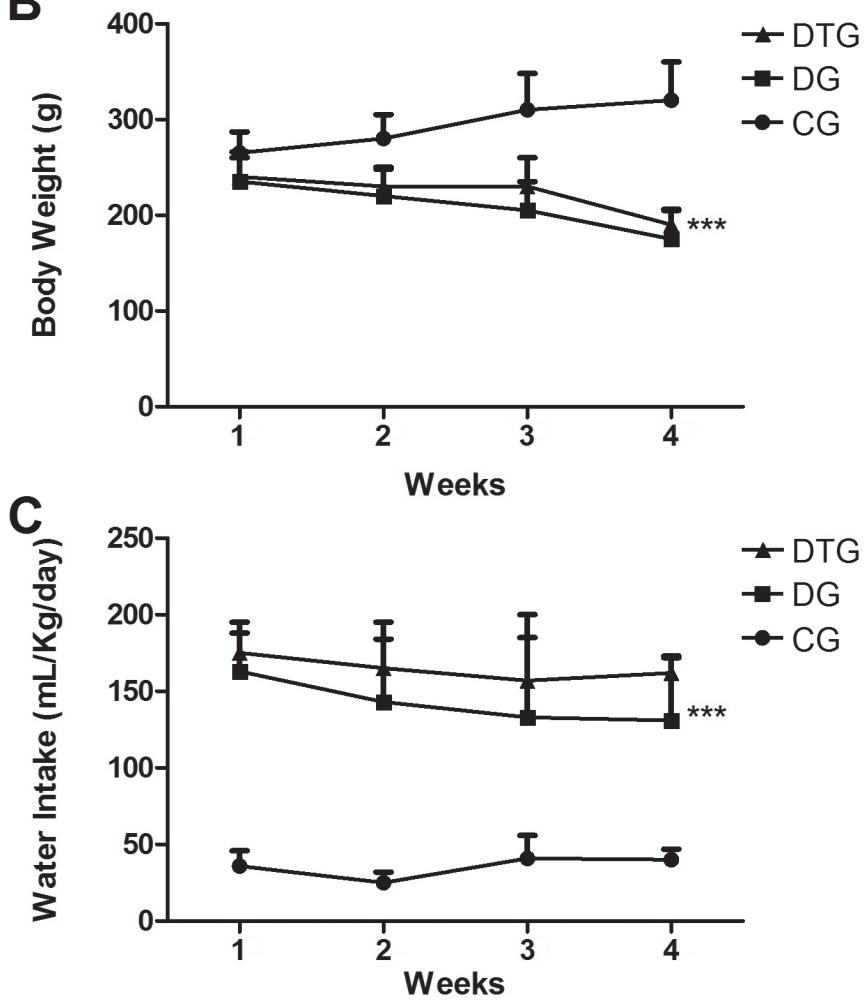

FIGURE 2 - Evaluation of fasting plasma glucose (A), body weight (B) and water intake (C) in groups CG (control), DG (diabetic) and DTG (diabetic Cissampelos sympodialis treatment) during the experimental 4-weeks protocol. Data appear as mean $\pm \mathrm{SD}^{* * *} \mathrm{p}<0,001$ in relation to $\mathrm{CG}$ versus DG.

\section{Biochemical analyses}

Four weeks after STZ-induced DM, there was a significant increase in fasting glycemia in the DG compared to the CG group $(\mathrm{p}<0.001)$ and treatment with CSE did not 
TABLE I - Biochemical analyses from Glucose, cholesterol and triglycerides

\begin{tabular}{lccc}
\hline & \multicolumn{3}{c}{ Experimental groups (n=10/group) } \\
\cline { 2 - 4 } & CG & DG & DTG \\
\hline Glucose, $(\mathrm{mg} / \mathrm{dL})$ & $84 \pm 19,40$ & $580 \pm 37,00^{* * *}$ & $567 \pm 32,10$ \\
Cholesterol, (mg/dL) & $46 \pm 18,90$ & $96 \pm 22,10^{* *}$ & $69 \pm 34,24 \#$ \\
Triacylglycerols,(mg/dL) & $35 \pm 17,30$ & $218 \pm 62,60 * * *$ & $133 \pm 66,80 \#$ \\
\hline
\end{tabular}

Data presented as mean \pm SD. CG, Control group, DG, diabetic group and DTG, diabetic Cissampelos sympodialis treatment group. ${ }^{* *} P<0.001, * * P<0.01 \mathrm{CG}$ versus DG and ${ }^{\#} P<0,05$ DG versus DTG.
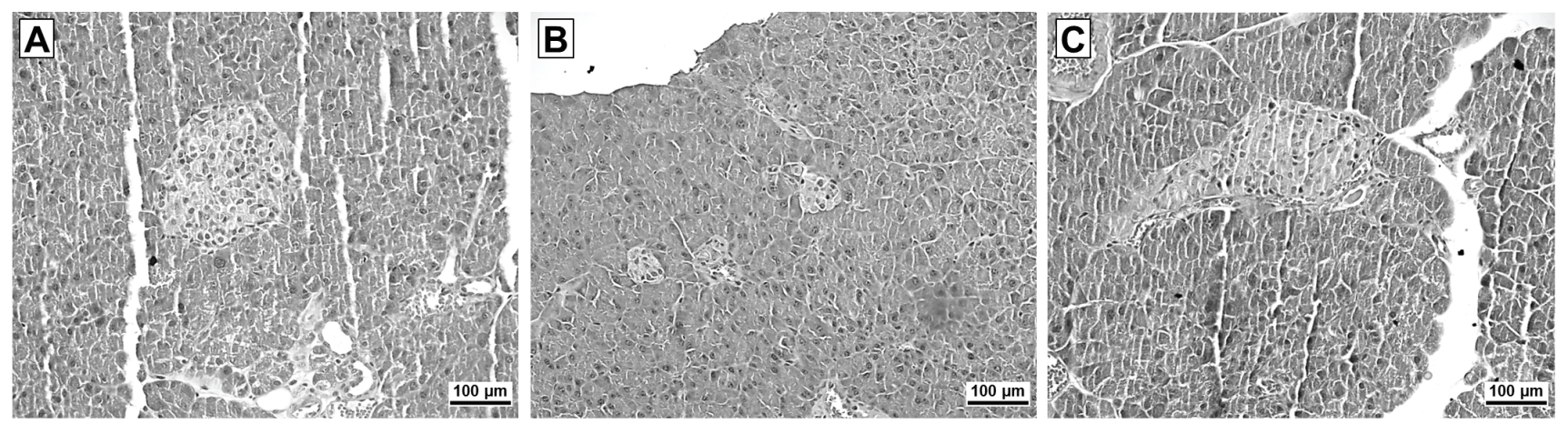

FIGURE 3 - Histology of pancreatic tissues stained by hematoxylin and eosin (HE) from Control group (A), Diabetes Mellitus group (B) and diabetic Cissampelos sympodialis treatment group (C). Magnification $100 \mathrm{X}$.

reduce this hyperglycemia (Table I). In relation to glycemic profile, the effect of treatment with CSE was similar to that of untreated rats (Figure 2A). Assessment of lipid profile showed that the CSE was capable of significantly reducing triglyceride and cholesterol concentrations $(\mathrm{p}<0.05)$, which were increased in DG (Table I).

\section{Morphological analyses}

The Figure 3 showed pancreatic architecture preserved in the $\mathrm{CG}$, which had large pancreatic islets between the various serous acini (Figure 3A). STZ caused shrinkage of islets of Langerhans in DG (Figure 3B). The significantly higher number of active pancreatic islets in the DTG group indicated that Cissampelos Sympodialis possibly protects the pancreatic islets against death and/or assisted the regeneration of these partially destroyed pancreatic islets (Figure 3C). These data were confirmed through the morphometry of pancreatic islets using the ImageJ software. Morphometric analysis revealed that STZ apparently shrank pancreatic islets evidenced by the significant reduction in their area. However, treatment with CSE was able to prevent damage on islets morphology maintaining the value of the area similar to control group (Figure 4).

The Figure 5 shows HE-stained lung tissue of experimental animals. In the $\mathrm{CG}$, the entire lung

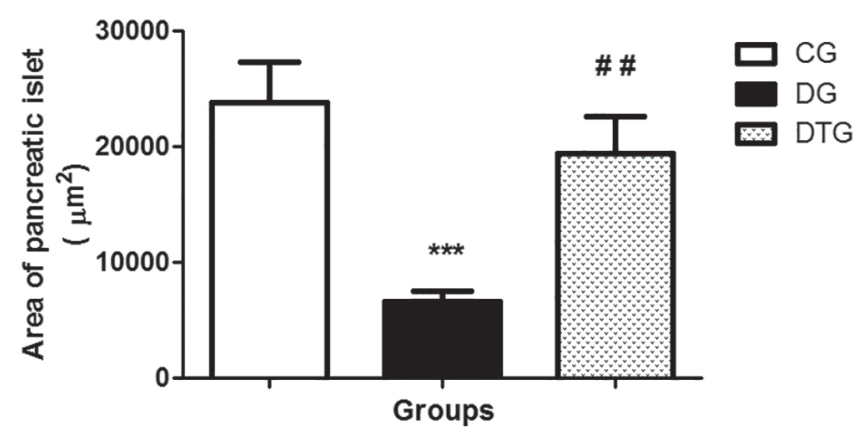

FIGURE 4 - Morphometric analysis of pancreatic islet in CG (control group), DG (diabetic group) and DTG (diabetic Cissampelos sympodialis treatment group). Data appear as mean $\pm \mathrm{SD} * * * \mathrm{P}<0.001$ in relation to $C G$ versus $\mathrm{DG}$ and \#\# $\mathrm{P}<0,01$ in relation to DG versus DTG.

architecture was preserved, exhibiting bronchioles with mucosa, submucosa and muscle layer, continuing with the spongy structure of the alveolar parenchyma, represented by numerous ducts and alveoli, whose walls or septa display a thin epithelial layer, supported by delicate connective tissue (Figure 5A). The lung morphology of the DG showed a loss of pulmonary architecture, due to the presence of the following histopathological findings: increase in alveolar septal thickness (Figure 5B), inflammatory exudate (Figure 5D), peribronchovascular inflammatory infiltrate (Figure 5E). Daily treatment with CSE showed an improvement in lung morphology when 
compared to DG animals, characterized by a reduction in inflammatory infiltrate (Figure 5C), and an absence in the other histopathological findings.

The Figure 6 shows lung tissue stained in picrosirius red from the same animals. The diabetic animals exhibited increased thickening of both the alveolar (Figure 6E) and bronchovascular wall (Figure 6B), reflected in the increased deposit of connective tissue in these pulmonary areas when compared with control animals. Treatment with CSE apparently reduced the thickening of these tissue structures (Figure 6C and 6F).

The most frequent lung findings (inflammation and tissue fibrosis) in diabetic animals were assessed by score and it was observed that treatment with CSE reduced the intensity of these findings in DM (Figure 7).

\section{DISCUSSION}

Type $1 \mathrm{DM}$ results from selective destruction of the insulin-producing $\beta$-cells in the pancreatic islets (Teoh et al., 2010). Hence, search for new agents that protect $\beta$-cells from destruction and thereby prevent DM is needed. Moreover, studies have been carried out in search of therapies for the negative effects caused by DM, and natural products have been the target of this research. The present study demonstrated the role of CSE in reducing the lipid profile and protecting against morphological alterations in the pancreatic islets and in the lungs caused by STZ-induced DM.

Studies using experimental diabetes models in rodents have been widely used for mimicking clinical aspects of human DM (Lerco et al., 2003; Oliveira et al., 2013). In the present study, polyuria, polydipsia, ponderal loss, and hyperglycemia, were observed during the entire experiment in diabetic animals induced by STZ. Although daily CSE administration did not reduce these clinical characteristics and hyperglycemia, CSE was able to prevent the pulmonary injury and mitigate pancreatic islet damage seen in diabetic rats.

Dyslipidemia, a common complication in diabetic patients, it is also a serious risk for cardiovascular diseases (Yadav, Moorthy, Baquer, 2005; Werle 2009; Mcgill et al., 2000). The present study showed that increased concentrations of triglycerides and cholesterol declined after treatment with CSE. According to J Chen and $\mathrm{Li}$ (2007), extracts containing flavonoids exhibit hypolipemiant activity. Similar results were observed in studies by Werle (2009) and El-Bassossy et al. (2013). In addition, research conducted by Cavalcante et al. (2010) demonstrated that the alkaloids present in CSE exert hypotensor and vasorelaxing effects. Thus, the presence of flavonoids associated to alkaloids found in CSE may be responsible for reducing the lipid profile as seen in DTG.

Type $1 \mathrm{DM}$ is believed to be initiated by
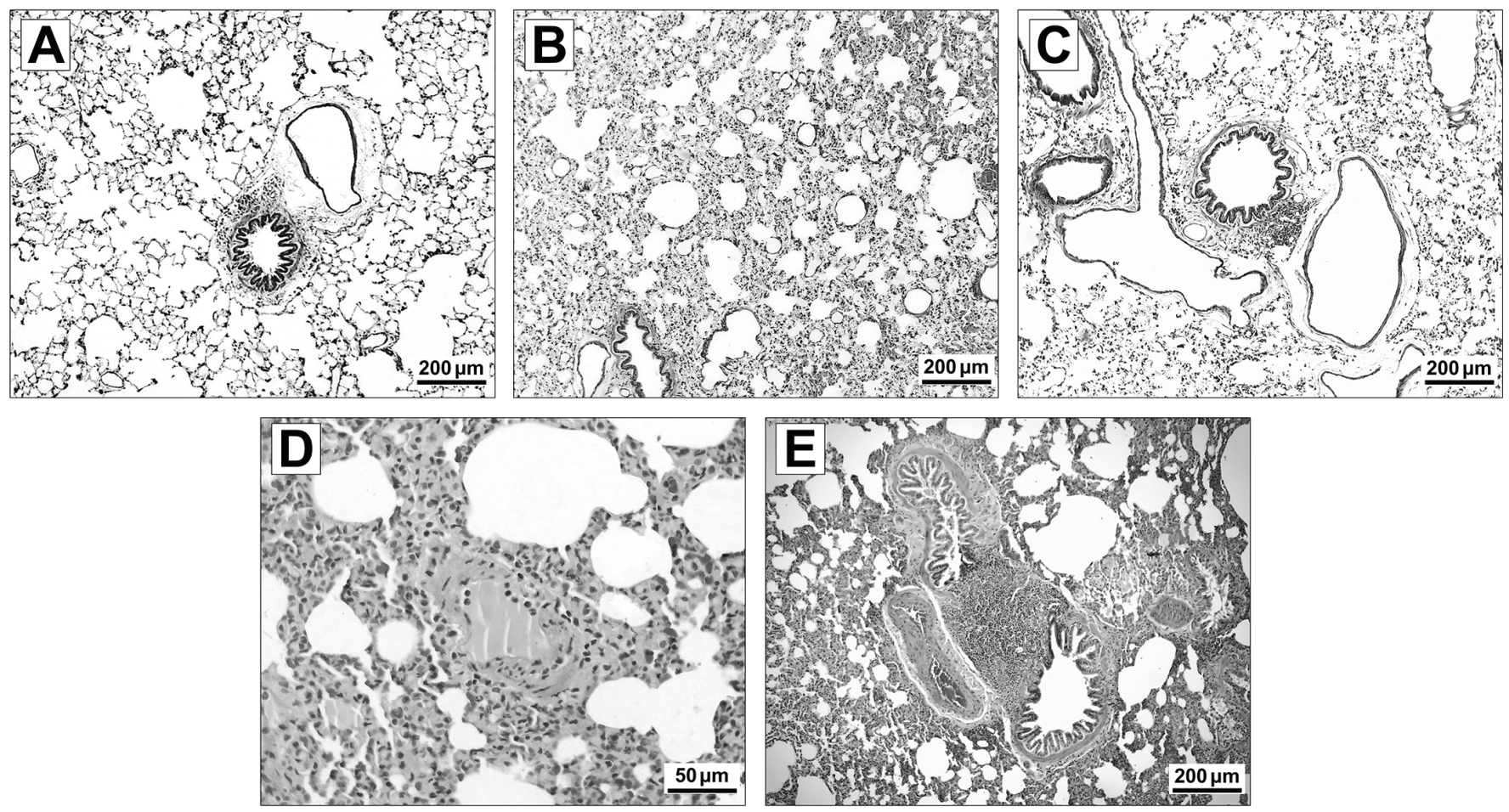

FIGURE 5 - Histology of lung tissue stained by hematoxylin and eosin (HE). Control group (A), Diabetes Mellitus group (B, D, E) and Diabetic Cissampelos sympodialis treatment group (C). Magnification 100X (A, B, C, E) and 400 X (D). 

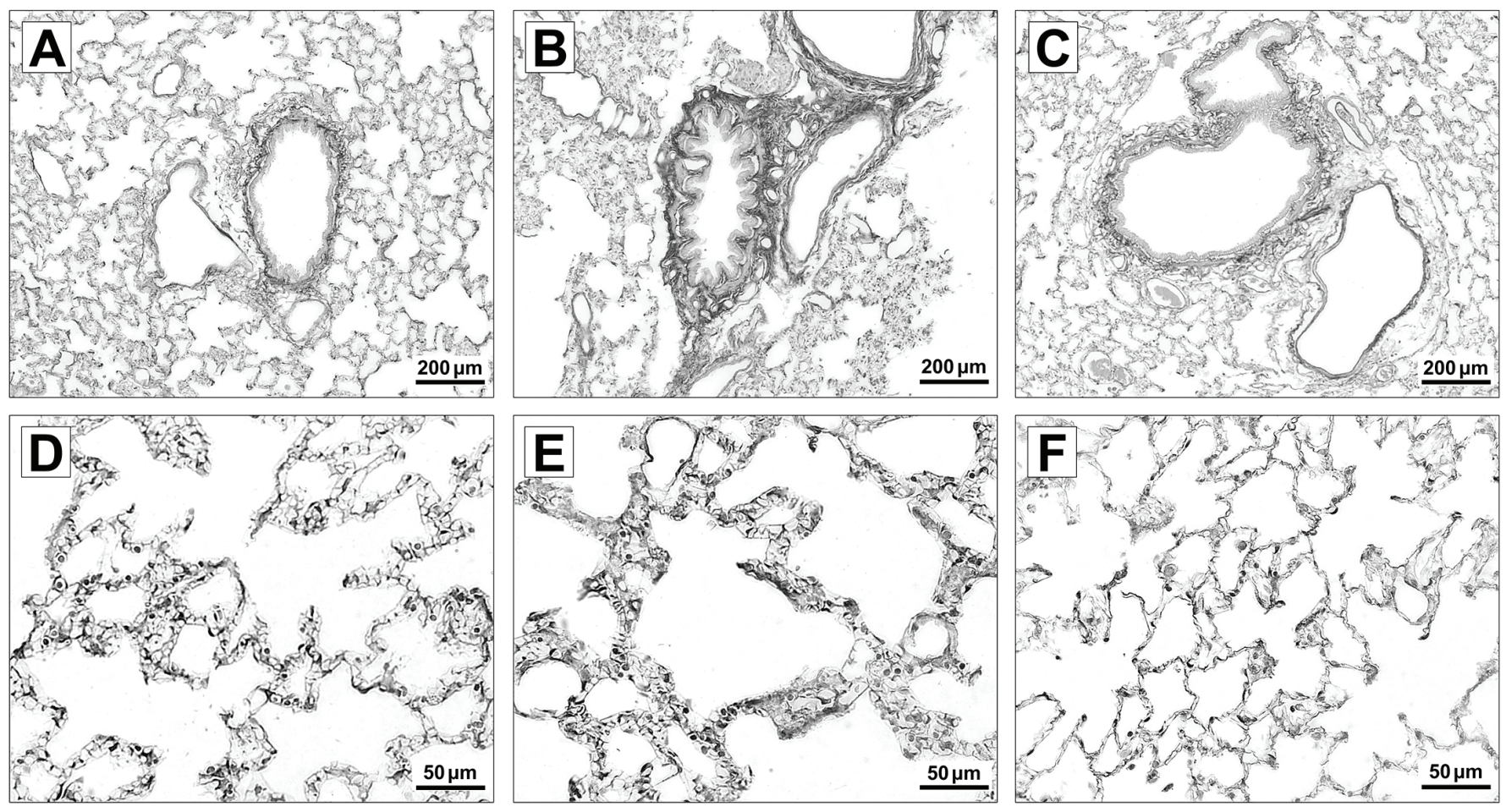

FIGURE 6 - Histology of lung tissue stained by picrusirius red. Control group (A, D), Diabetes Mellitus group (B, E) and Diabetic Cissampelos sympodialis treatment group (C, F). Magnification 100X (A, B, C) and $400 \mathrm{X}(\mathrm{D}, \mathrm{E}, \mathrm{F})$.

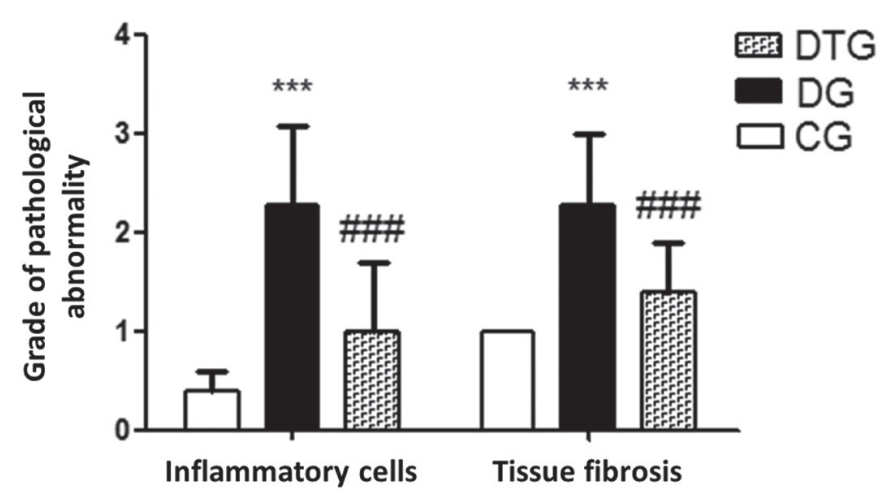

FIGURE 7 - The lung injury score (inflammation cells and tissue fibrosis) in different groups. Lung fragments were removed 24 hours after the last day of the experiment and stained with hematoxylin and eosin (HE), at 100x magnification. Data appear as mean $\pm \mathrm{SD}$. CG (control group), DG.

autoimmune destruction of $\beta$-cell or islet, sources of insulin. T cells recognising $\beta$-cell specific antigens become activated infiltrate the inflamed islets and attack the $\beta$-cells (Gulle et al., 2014). In our study, histopathological examination and injury score of the islets of pancreas showed that CSE treated animals had a better morphological preservation of pancreatic islets compared to DTG. The better preservation of islets when the animals were treated with CSE can be directly related to the antiinflammatory property of CSE. Previous phytochemical works have described the presence of five alkaloids in the hydro-alcoholic CSE: warifteine, metilwarifteine, roraimine, liriodenine and milonine (Cortes et al., 1995; De Lira et al., 2002) Warifteine (Wa) is the more abundant alkaloid in CSE, having its anti-inflammatory and immune modulatory properties mainly related to the modulation of the production and migration in vivo and in vitro of inflammatory cells such as neutrophils, eosinophils, macrophages and lymphocytes (Lima et al., 2014; Costa et al., 2008). Thus, it is possible that these substances are involved in modulating inflammation and exert protective effect on pancreatic islets cells.

Assessment of the morphological characteristics of lung tissue showed that diabetic animals exhibited different pulmonary structure when compared to healthy rats. Increase in bronchovascular wall thickening, presence of inflammatory infiltrate and pulmonary edema were some of the anatomopathological findings, corroborating other studies (Goldman, 2003; Eren et al., 2010; Spadella et al., 2010; Hagiwara et al., 2011). These investigations also demonstrated morphofunctional alterations in the lung tissue of diabetic rats. Treatment with CSE was effective in preventing the morphological alterations observed in animals treated with STZ.

Studies carried out by Plopper, Morishige (1978) showed increased synthesis and less degradation of collagen and elastin in the lungs of diabetic rats, evidenced by increased bronchovascular wall thickness. Similar 
morphological alterations were observed in diabetic lungs in our study, which were mitigated with CSE treatment.

Browlee (2001) reported that oxidative stress is related to possible signaling pathways associated with the chronic complications of DM, such as the polyphenol pathway, protein kinase $\mathrm{C}$ (PHC) activation and the pathway of advanced glycation end-products (AGEs). For this reason, a number of studies have demonstrated that the exogenous use of antioxidant substances reduces systemic damage caused in the physiopathology of DM, indicating their therapeutic potential for treating diabetic subjects (Dias et al., 2005; Bojunga et al., 2004). Ribeiro et al. (2008) showed that alkaloids exert intense antioxidant activity. Given that primary component in CSE is alkaloid (Barbosa-Filho, Agra, Thomas, 1997; Marinho, BarbosaFilho, Oliveira, 2011), antioxidant activity may be one of the mechanisms responsible for the protective effect on lung morphology observed in the present study.

In this experimental model, acute therapy with CSE was capable to ameliorate lipid profile, the pancreatic islet damage and to preserve the pulmonary architecture of diabetic animals induced by STZ through a still unknown mechanism, but independent of glycemia. Therefore, these findings reveal the therapeutic potential of Cissampelos sympodialis on the pulmonary physiopathology of DM.

\section{ACKNOWLEDGEMENTS}

We thank Maria de Socorro M. Amarantes, Melyna S. Souto and Maria de Lourdes Freitas (Department of Morphology, CB, Federal University of Rio Grande do Norte) for expert assistance in histology. This work was supported by Conselho Nacional de Desenvolvimento Científico e Tecnológico (CNPq -14/2010) and Fundação de Amparo a Pesquisa do Estado do Rio Grande do Norte (FAPERN- PPP-3).

\section{REFERENCES}

Agra MF, França PF, Barbosa-Filho JM. Synopsis of the plants known as medicinal and poisonous in northeast of Brazil. Rev Bras Farmacogn. 2007;17(1):114-140.

Almeida RN, Melo-Diniz MFF, Medeiros IA, Quintans LJ, Navarro DS, Falcao A, Duarte JC, Barbosa JM. Anorectic and behavioural effects of chronic Cissampelos sympodialis treatment in female and male rats. Phytother Res. 2005;19(2):121-124.
Aragão CFS. Desenvolvimento de metodologias analíticas para padronização de extratos de Cissampelos sympodialis Eichl (Milona). 210p. Tese (Doutorado). Laboratório de Tecnologia Farmacêutica da Universidade Federal da Paraíba, João Pessoa; 2012.

Barbosa-Filho JM, Agra MF, Thomas G. Botanical, chemical, pharmacology investigation on Cissampelos species from Paraíba (Brazil). Ciênc Cult. 1997;49(5/6):386-394.

Batista-Lima KV, Ribeiro RA, Balestieri FMP, Thomas G, Piuvezam MR. Anti-inflammatory activity of Cissampelos sympodialis Eichl. (Menispermaceae) leaf extract. Acta Farm Bonaerense. 2001;20(4):275-9.

Bezerra-Santos CR, Vieira-De-Abreu A, Vieira GC, Filho JR, Barbosa-Filho JM, Pires AL, Martins MA, Souza HS, Bandeira-Melo C, Bozza PT, Piuvezam MR. Effectiveness of Cissampelos sympodialis and its isolated alkaloid warifteine in airway hyperreactivity and lung remodeling in a mouse model of asthma. Int Immunopharmacol. 2012;13(2):148-155.

Bojunga J, Dresar-Mayert B, Usadel Kh, Kusterer K, Zeuzem $\mathrm{S}$. Antioxidative treatment reverses imbalances of nitric oxide synthase isoformexpression and attenuates tissuec GMP activation in diabetic rats. Biochem Biophys Res Commun. 2004;316(3):771-780.

Brownlee M. Biochemistry and molecular cell biology of diabetic complications. Nature. 2001;414(6865):813-820.

Carvalho EN, Carvalho NAS, Ferreira LM. Experimental model of induction of diabetes mellitus in rats. Acta Cir Bras. 2003;18(n esp):60-64.

Cavalcante HM, Ribeiro TP, Silva DF, Nunes XP, Diniz MF, Correia NA, Braga VA, Medeiros IA. Cardiovascular effects elicited by milonine, a New 8,14-dihydromorphinandienone alkaloid. Basic Clin Pharmacol Toxicol. 2011;108(2):122-130.

Chawla A, Chawla R, Jaggi S. Microvasular and macrovascular complications in diabetes mellitus: Distinct or continuum? Indian J Endocrinol Metab. 2016;20(4):546-51.

CIOMS, ICLAS. International guiding principles for biomedical research involving animals. Council for International Organization of Medical Sciences (CIOMS) and International Council for Laboratory Animal Science (ICLAS). 2012. [Accessed 18 Feb 2018]. Available at: http://www.cioms.ch/ images/stories/CIOMS/IGP2012.pdf. 
Cortes SF, Alencar, JL, Thomas GA, Barbosa-Filho JM. Spasmolytic actions of warifteine, a bisbenzylisoquinoline alkaloid isolated from root bark of Cissampelos sympodialis Eichl. Phytother Res. 1995;9(8):579-583.

Costa HF, Bezerra-Santos CR, Barbosa-Filho JM, Martins MA, Piuvezam MR. Warifteine, a bisbenzylisoquinoline alkaloid, decreases immediate allergic and thermal hyperalgesic reactions in sensitized animals. Int Immunopharmacol. 2008;8(4):519525.

Costa HF, Leite FC, Alves AF, Barbosa-Filho JM, Dos Santos $\mathrm{CR}$, Piuvezam MR. Managing murine food allergy with Cissampelos sympodialis Eichl (Menispermaceae) and its alkaloids. Int Immunopharmacol. 2013;17(2):300-308.

Cerqueira-Lima AT, Alcântara-Neves NM, De Carvalho LC, Costa RS, Barbosa-Filho JM, Piuvezam M, et al. Effects of Cissampelos sympodialis Eichl. and its alkaloid, warifteine, in an experimental model of respiratory allergy to Blomia tropicalis. Curr Drug Targets. 2010;11(11):1458-1467.

Davis TM, Knuiman M, Kendall P, Davis A. Reduced pulmonary function and its associations in type 2 diabetes, the fremantle diabetes study. Diabetes Res Clin Pract. 2000;50(2):153-159.

De Lira GA, De Andrade LM, Florêncio KC, Da Silva MS, Barbosa-Filho JM. Roraimine, a bisbenzylisoquinoline alkaloid from Cissampelos sympodialis roots. Fitoter. 2002;73(4):356358.

De Sales IR, Machado FD, Marinho AF, Lúcio AS, Barbosa Filho JM, Batista LM. Cissampelos sympodialis Eichl. (Menispermaceae), a medicinal plant, presents antimotility and antidiarrheal activity in vivo. BMC Complement Altern Med. 2015;25:247-253.

Dias AS, Porawski M, Alonso M, Marroni N, Collado PS, González-Gallego J. Quercetin decreases oxidative stress, NF-kappaB activation, and iNOS overexpression in liver of streptozotocin-induced diabetic rats. J Nutr. 2005;135(10):22992304.

El-Bassossy, Hany M, Abo-Warda, Shaymaa M, Fahmy A. Chrysin and luteolin attenuate diabetes-induced impairment in endothelial-dependent relaxation, effect on lipid profile, AGEs and NO generation. Phytother Res. 2013;27(11):1678-84.
Eren G, Cukurova Z, Hergunsel O, Demir G, Kucur M, Uslu E, Dalo E, Uhri M, Tugcu V. Protective effect of the nuclear factor Kappa B inhibitor pyrrolidine dithiocarbamate in lung injury in rats with streptozotocin-induced diabetes. Respiration. 2010;79(5):402-10.

Goldman MD. Lung dysfunction in diabetes. Diabetes Care. 2003;26(6):1915-1918.

Gulle K, Ceri NG, Akpolat M, Arasli M, Demirci B. The effects of dexpanthenol in streptozotocin-induced diabetic rats, Histological, histochemical and immunological evidences. Histol Histopathol. 2014;29(10):1305-13.

Hagiwara S, Iwasaka H, Shingu C, Matumoto S, Hasegawa A, Noguchi T. The effect of experimental diabetes on high mobility Group Box 1 protein expression in endotoxin-induced acute lung injury. J Surg Res. 2011;168(1):111-118.

Halim M, Eshrat T, Hussain S, Ali N. Hipoglycemic and antioxidant properties of combination of curcumim from curcuma longa, Linn, and partially purified product from abroma Augusta, Linn. in Streptozotocin induced Diabetes. Indian J Clin Biochem. 2002;17(2):33-43.

J Chen and Li. Hypolipidemic effect of flavonoids from mulberry leaves in triton WR-1339 induced hyperlipidemic mice. Asia Pac J Clin Nutr. 2007;16(Suppl):290-294.

Knip M, Simell O. Environmental triggers of type 1 diabetes. Cold Spring Harb Perspect Med. 2012;2(7):1-15.

Lerco M, Spadella CT, Machado JLM, Schellini AS, Padovani CR. Caracterização de um modelo experimental de Diabetes Mellitus induzido pela aloxana em ratos. Acta Cirúrgica Brasileira. 2003;18(2):132-142.

Lima TF, Rocha JD, Guimarães-Costa AB, Barbosa-Filho JM, Decoté-Ricardo D. Warifteine, an alkaloid purified from Cissampelos sympodialis, inhibits neutrophil migration in vitro and in vivo. Immunol Res. 2014;2014:752923.

Marinho AF, Barbosa-Filho JM, Oliveira EJ. A validated method for the simultaneous quantitation of bioactive alkaloid markers in the leaf ethanolic extract of Cissampelos sympodialis Eichl.: a phenological variation study. Phytochem Anal. 2012;23(5):42632.

Mcgill HC, Mcmahan CA, Herderick EE, Malcom GT, Tracy RE, Strong JP. Origin of atherosclerosis in childhood and adolescence. Am J Clin Nutr. 2000;72(5):1307-1315. 
Mejía-León ME, Ruiz-Dyck KM, Calderón AM, De La Barca. HLA-DQ genetic risk gradient for type 1 diabetes and celiac disease in North-Western Mexico. Rev Gastroenterol. 2015;80(2):135-143.

Melo PS, Cavalcante HM, Barbosa-Filho JM, Diniz MF, Medeiros IA, Haun M. Warifteine and milonine, alkaloids isolated from Cissampelos sympodialis Eichl, cytotoxicity on rat hepatocyte culture and in V79 cells. Toxicol Lett. 2003;142(12):143-151.

Naso FC, De Mello RN, Bona S, Dias AS, Porawski M, Ferraz Adeb, Richter MF, Marroni NP. Effect of Agaricus blazei Murill on the pulmonary tissue of animals with streptozotocin-induced diabetes. Exp Diabetes Res. 2010a;2010:543926.

Naso FC, Forgiarini Junior LA, Forgiarini LF, Garrido MP, Dias AS, Marroni NA. Aminoguanidina reduz o estresse oxidativo e as alterações estruturais pulmonares em diabetes mellitus experimental. J Bras Pneumol. 2010b;36(4):485-489.

Oliveira FS, Nessler RA, Castania JA, Salgado HC, Fazan VP. Ultrastructural and morphometric alterations in the aortic depressor nerve of rats due to long term experimental diabetes: effects of insulin treatment. Brain Res. 2013;23(1491):197-203.

Özşahin KA, Tugrul S, Mert M, Yuksel, Tugrul G. Evaluation of pulmonary alveolo-capillary permeability in type 2 diabetes mellitus. Using technetium 99 mTc-DTPA aerosol scintigraphy and carbon monoxide diffusion capacity. J Diabetes Complications. 2006;20(4):205-209.

Plopper CG, Morishige WK. Alterations in granular (type II) pneumocyte ultrastructure by streptozotocin-induced diabetes in the rat. Lab Invest. 1978;38(2):143-148.

Popov D, Simionescu M. Alterations of lung structure in experimental diabetes, and diabetes associated with hyperlipidaemia in hamsters. Eur Respir J. 1997;10(8):18501858.

Porto NM, Lima DBIJ, Agra MF. Pharmacobotanical study of the leaves of Cissampelos sympodialis Eichl., (Menispermaceae). Rev Bras Farmacogn. 2008;18(1):102-107.
Ribeiro B, Andrade PB, Silva PBM, Seabra RM, Valentão P. Comparative study on free amino acid composition of wild edible mushroom species. J Agric Food Chem. 2008;56(22):10973-10979.

Shukri R, Mohamed S, Mustapha NM, Hamid AA. Evaluating the toxic and beneficial effects of jering beans (Archidendron jiringa) in normal and diabetic rats. J Sci Food Agric. 2010;91(14):2697-2706.

Spadella CT, Suarez OA, Lucchesi AN, Cataneo AJ. Pancreas transplantation prevents morphologic and ultrastructural changes in pulmonary parenchyma of alloxan-induced diabetic rats. Transplant Proc. 2010;42(6):2092-2096.

Teoh SL, Aziab ABD Latiff, Das S. Histological changes in the kidneys of experimental diabetic rats fed with Momordica charantia (bitter gourd) extract. Romanian J Morphol Embryol. 2010;51(1):91-95.

Vieira GC, De Lima JF, De Figueiredo RC, Mascarenhas SR, Bezerra-Santos CR, Piuvezam MR. Inhaled Cissampelos sympodialis down-regulates airway allergic reaction by reducing lung CD3 + TCell. Phytother Res. 2012;27(6):916-925.

Walter RE, Beiser A, Givelber RJ, O'connor GT, Gottlieb DJ. Association between glycemic state and lung function, the Framingham Heart Study. Am J Respir Crit Care Med. 2003;167(6):911-916.

Werle ALB. Avaliação da atividade de Casearia sylvestris Swartz (Flacourtiaceae) sobre os níveis séricos de triglicerídeos em ratos. Rev Bras Farmacogn. 2009;19(2a):400-402.

Weynand B, Jonckheere A, Frans A, Rahier J. Diabetes mellitus induces a thickening of the pulmonary basal lamina. Respiration. 1999;66(1):14-19.

Yadav UC, Moorthy K, Baquer NC. Combined treatment of sodium orthovanadate and Mormodica charantia fruit extract prevents alterations in lipid profile and lipogenic enzymes in alloxan diabetic rats. Mol Cell Biochem. 2005;268(1-2):111120.
Received for publication on $14^{\text {th }}$ July 2017 Accepted for publication on $10^{\text {th }}$ Ocotber 2018 